\title{
Perception of Certified Organic Farmers towards Organic Farming Practices - An Ex Post Facto Study
}

\author{
H. Philip ${ }^{1^{*}}$ and P. Sivaraj ${ }^{2}$ \\ ${ }^{1}$ Director of Extension Education, Tamil Nadu agricultural University, Coimbatore, \\ Tamil Nadu, India \\ ${ }^{2}$ RVS Agricultural College (Affiliated to TNAU, Coimbatore-3), Thanjavur, Tamil Nadu, India \\ *Corresponding author
}

\begin{tabular}{|c|}
\hline Keywords \\
\hline $\begin{array}{l}\text { Eco-friendly conservation, } \\
\text { Environmental degradation, } \\
\text { Organic manure, Profitability } \\
\text { Perception }\end{array}$ \\
\hline Article Info \\
\hline $\begin{array}{l}\text { Accepted: } \\
\text { 04 November } 2018 \\
\text { Available Online: } \\
\text { 10 December } 2018\end{array}$ \\
\hline
\end{tabular}

\section{A B S T R A C T}

The study was conducted at Coimbatore, Erode and Tiruppur districts of Tamil Nadu. From each of districts three blocks were selected purposively and a sample of 20 certified organic farmers were selected from each of the blocks through purposive sampling. A total of 180certified organic farmers were surveyed for the study. From the study area half $(50.55 \%)$ of the certified organic farmers had high level of perception on eco-friendly conservation practices followed by low $(26.11 \%)$ and medium $(23.34 \%)$. More than half $(53.33 \%)$ of the certified organic farmers had medium level of perception on use of organic manures followed by high $(31.67 \%)$ and low $(15.00 \%)$ levels of perception on use of organic manures. Majority (59.44\%) of the certified organic farmers had medium level of perception on profitability of organic farming, followed by high $(23.89 \%)$ and low $(16.67 \%)$ level of perception on profitability of organic farming. Majority of the certified organic farmers had medium level of perception on environmental degradation followed by high $(29.45 \%)$ and only 10.00 per cent of the certified organic farmers fell under low level category. Hence, the extension system needs to be strengthened so as to provide information on significance of organic farming.

\section{Introduction}

Organic farming is not only revival to the farming community, but also to the consumers to lead a "Healthy and Happy life". All the certified organic farmers should have gained the basic understanding about the eco-friendly conservation practices as part of organic farming practices. These might be due to greater yield stability, especially reduced cost on pest and disease control measures, higher yields and incomes in organic farming systems. In addition to that organic produce prefer premium price in high end market that evidenced by the organic farmers over the period of time. Organic farming has been widely recognized alternative farming system to chemical agriculture evolved during 1940's largely in response to the publication of J.I Rodale in the U.S. Lay Eve Bayour in England and Sir Albert Howard in India. In 1980, USDA released a landmark report on organic farming. Which revealed that the "Organic farming is a production system, which avoids or largely excludes the use of synthetically 
compounded fertilizers, pesticides, growth regulators and livestock feed additives to the maximum extent feasible, organic farming systems rely upon crop rotations, crop residues, animal manures, legumes, green manures, off-farm organic wastes, mechanical cultivation, mineral bearing rocks and aspects of biological pest control to maintain soil productivity and tilth to supply plant nutrients and to control insects, weeds and other pests".

Organic farming can be seen as an approach to agriculture where the aim is to create integrated, sustainable agricultural production systems. Conventional farming is based on the use of high yielding varieties of seeds, chemical fertilizer, irrigation water, pesticides etc. Promoting organic farming practices among the farming community in a large scale will be a promising strategy to face these challenges (Elavarasi and Ponnusamy, 2015). Organic farming improves the soil's biological properties such as supply and retention of soil nutrients and promotes favourable chemical reactions, production of clean foods, improves the soil physical properties such as granulation and good tilth, good aeration and easy root penetration, improves water holding capacity in sustaining production system which is largely dependent on on-farm resources (Thiripurasundari et al., 2015).

Sustainability in agriculture production system and ecological stability are the important issues, which renewed the interests of farmers and researchers to opt for organic sources of plant nutrients like panchakavya, jeevamirtha, amudhakaraisal, fish amino acid, biofertilizers and organic manures viz., farmyard manure, vermicompost, poultry manure and green manure. Awareness of soil health and crop quality has led to an interest towards ecofriendly farming practices safety environment system such as organic farming (Sharma et al., 2008). Increased awareness of health and environmental issues associated with the intensive use of chemical inputs has led to the interest of alternate agriculture. Organic farming is one such methods which boosters environmental sustainability (Ramesh et al., 2005).

Organic farming was practiced in India from time immemorial. The great Indian civilization thrived on organic farming. In traditional India, the entire agriculture was practiced using organic techniques, where the fertilizers, pesticides, etc., were derived from plant and animal products. The traditional farming system was attributed only with the effect of small and marginal farmers, who produce food and basic animal products to make out a living and for the livelihood of locals. Organic farming is the best option to attain sustainability in crop production. Based on this background the study was conducted among 180 certified organic farmers in Coimbatore, Erode and Tiruppur districts of Tamil Nadu to find out their marketing behavior in selected dimensions

\section{Materials and Methods}

\section{Study Area}

The Western zone of Tamil Nadu viz. Coimbatore, Erode and Tiruppur districts were selected purposively, as maximum numbers of organic farmers have registered under the category of individual certified organic farmers. Practising organic farming in different crops like coconut, banana, pulses and turmeric from the study area.

\section{Research Design}

Ex post facto research design evolved for the study. A total sample size of 180 certified organic farmers are selected for the study. A sample size of 60 organic farmers was considered for the study in each of the districts such as Coimbatore, Erode and Tiruppur 
respectively. In each district, three blocks were selected and in each block 20 certified organic farmers were selected through Purposive random sampling method.

\section{Data collection tools}

A well-structured and pre-tested interview schedule was used for data collection. Keeping in view, the objectives and the variables under study, a comprehensive semi structured interview schedule covering all aspects of organic farming practices was prepared. The items included in the interview schedule were structured questions and objective type questions which were suitable to all categories of organic farmers. The most relevant, unambiguous and practical questions were included in the schedule duly avoiding irrelevant items. Each of the selected certified organic farmers was contact personally and interviewed.

\section{Statistical analysis}

The data collected were subjected to statistical analysis to get inferences. Percentage analysis was used in descriptive analysis for making simple comparisons. For calculating percentage, the frequency of the particular cell was multiplied by 100 and divided by the total number of respondents pertaining to particular cell.

\section{Results and Discussion}

\section{Perception on eco friendly conservation practices}

Perception is an act or power of perceiving or apprehending or combining the sensations into recognition of an object or stimulus. The perception of eco-friendly conservation practices supports to save the environment in relation to eco-consequence by the farmers. The distribution of the farmers according to their level of eco-friendly conservation practices is presented in Table 1 .

Table 1, shows that half $(50.55 \%)$ of the certified organic farmers had high level of perception on eco-friendly conservation practices followed by low $(26.11 \%)$ and medium $(23.34 \%)$. The reason might be due to the fact that majority of them had high level educational status with medium level of scientific orientation, mass media exposure and extension agency contact.

Eco friendly conservation practices and organic farming came under the production management system which ensures the agro ecosystem health, including biodiversity, biological cycles and soil biological activity. It helps to control pests, use of pest resistant varieties, preservation and conservation of household waste, increased use of biofertilizer, farm yard manure and compost as the best soil microbial activity without affecting the environment health.

The above facts were clearly understood by the certified organic farmers and acted accordingly. Eco-friendly plant protection were measures effectively practiced in the study area, by practicing chemical free inputs, manures, planning trap crops like neem, pungam, papaya, castor etc.

\section{Perception on use of organic manures}

The distribution of respondents according to their perception on use of organic manures is furnished in Table 2.

The result depicted in Table 2 that more than half $(53.33 \%)$ of the certified organic farmers had medium level of perception on use of organic manures followed by high $(31.67 \%)$ and low $(15.00 \%)$ levels of perception on use of organic manures. 
Table.1 Distribution of respondents according to their perception on eco friendly conservation practices

\begin{tabular}{|c|l|c|c|c|}
\hline S. No. & \multicolumn{2}{|c|}{ Category } & Number & Per cent \\
\hline 1. & Low & 47 & 26.11 \\
\hline 2. & Medium & 42 & 23.34 \\
\hline 3. & High & 91 & 50.55 \\
\hline & & Total & $\mathbf{1 8 0}$ & $\mathbf{1 0 0 . 0 0}$ \\
\hline
\end{tabular}

$(n=180)$

Table.2 Distribution of respondents according to their perception on use of organic manures

\begin{tabular}{|c|l|c|c|c|}
\hline S. No. & \multicolumn{2}{|c|}{ Category } & Number & Per cent \\
\hline 1. & Low & & 27 & 15.00 \\
\hline 2. & Medium & & 96 & 53.33 \\
\hline 3. & High & & 57 & 31.67 \\
\hline & & Total & $\mathbf{1 8 0}$ & $\mathbf{1 0 0 . 0 0}$ \\
\hline
\end{tabular}

Table.3 Distribution of respondents according to their perception on profitability of organic farming

\begin{tabular}{|c|c|c|c|}
\hline S. No. & Category & Number & Per cent \\
\hline 1. & Low & 30 & 16.67 \\
\hline 2. & Medium & 107 & 59.44 \\
\hline 3. & High & 43 & 23.89 \\
\hline & Total & 180 & 100.00 \\
\hline
\end{tabular}

Table.4 Distribution of respondents according to their perception on the environmental degradation

\begin{tabular}{|c|l|c|c|c|}
\hline \multicolumn{2}{|c|}{ Category } & Number & Per cent \\
\hline S. No. & \multicolumn{1}{|c|}{ c180) } \\
\hline 1. & Low & & 18 & 10.00 \\
\hline 2. & Medium & High & 109 & 60.55 \\
\hline & & Total & $\mathbf{1 8 0}$ & 29.45 \\
\hline
\end{tabular}

The application of organic manure in farm not only helps to grow good quality produce, but also for the safe agro ecosystem with earthworms and other beneficial insects. Organic manures helps to create safe haven for people, animals and living things. This may be probable reason for majority of the organic farmers with medium to high level category on the perception on use of organic manures. A majority of the farmers perceived the importance of animal manure, crop residue and in situ incorporation of green manures in the soil and by the use of other composts viz. vermicompost, coir pith compost, FYM, green manuring and biofertilizers viz. Rhizobium, Azotobacter, Azospirillum, Blue-green algae, Azolla and Mycorrhizae, for better organic farming. 
Hence, majority of them had good perception on the importance of organic manures.

\section{Perception on profitability of organic farming}

The distribution of the respondents according to their perception on profitability of organic farming is given in Table 3.

A glance at the Table 3 revealed that majority $(59.44 \%)$ of the certified organic farmers had medium level of perception on profitability of organic farming, followed by high $(23.89 \%)$ and low (16.67\%) level of perception on profitability of organic farming.

This may be due to fact that certified organic farmers usually get higher prices than conventional farm produce. The organic farmers have also realized the profitability due to selling and certified organic produce in local and distance markets.

Likewise, cost of cultivation was also reduced due to the low external and low cost of inputs for organic farming. This may be the reason for majority of them had medium to high level of perception on profitability of organic farming.

\section{Perception on environmental degradation}

The perception on environmental degradation indicates the negative impact of environmental degradation. The distribution of respondents according to their perception on environmental degradation is given in Table 4.

It is evident from the Table 4 that majority of the certified organic farmers had medium level of perception on environmental degradation followed by high $(29.45 \%)$ and only 10.00 per cent of the certified organic farmers fell under low level category.
The certified organic farmers convert their land into organic farming, experienced problems in practicing inorganic farming. High dose of fertilizer, use of pesticides and fungicides have contaminated the soil and agro ecosystems which evinced through soil test analysis and pollution test level. Likewise, environmental degradation due to excessive use of chemicals was also well explained during all the training programmes. Hence, majority of the farmers had medium to high level of perception on environmental degradation.

Farmers had high to medium level of perception towards organic farming practices in study area. Hence, the extension system need to be strengthened so as to provide information on significance of organic farming as well as organic cultivation practices, market information and improve the knowledge of the farmers regarding ongoing organic farming related government schemes. This is a great opportunity for rural unemployed youths to establish the organic input preparation unit as an enterprise with support of government and NGOs, which will support the livelihood security of youth and increases the organic input production. The environmental importance of organic farming and its produces may be included to school children by establishing organic nutrition garden in all residential and tribal school institutions. Policy interventions should be made in order to establish organic based special economic zones.

\section{References}

Elavarasi, M and Ponnusamy, K. A. 2015. Reasons for Resorting to Organic Farming and Advantages Perceived by the Organic Farmers. J. of Ext. Edu. 27 (3). Pp 5485-5493.

Ramesh, P., M. Singh and S. Rao. A. 2005. Organic Farming: It's Relevance to the 
Indian Context. Current Science, 88: 561-568.

Sharma, M., C.S. Pandey and B.S. Mahapatra. 2008. Effect of Bio fertilizers on Yield and Nutrient uptake by Rice and Wheat in Rice-Wheat Cropping System under Organic mode of Cultivation. J. Ecofriendly Agric., 3(1):19-23.
Thiripurasundari, K and Divya, V. 2015. Factors Determining the Adoption of Organic Farming among the Farming Community in Tamil Nadu. Int. $J$ of Commerce, Business and Management. Vol. 4(2). Pp 1039-1044.

\section{How to cite this article:}

Philip, H. and Sivaraj, P. 2018. Perception of Certified Organic Farmers towards Organic Farming Practices - An Ex Post Facto Study. Int.J.Curr.Microbiol.App.Sci. 7(12): 56-61. doi: https://doi.org/10.20546/ijcmas.2018.712.008 